EQUILIBRIUM JOURNAL OF

CHEMICAL ENGINEERING

Homepage:https://jurnal.uns.ac.id/equilibrium

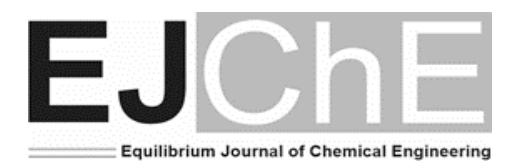

\title{
Pemurnian Minyak Biji Kesambi (Schleichera oleosa) Sebagai Bahan Baku Pembuatan Minyak Goreng
}

\author{
Firda Dwita Putri, Aditya Surya Pratama, Fasha El Sauzsa, Dwi Ardiana Setyawardhani* \\ Program Studi Teknik Kimia, Fakultas Teknik, Universitas Sebelas Maret, Surakarta, Indonesia 57126 \\ *Corresponding author: dwiardiana@staff.uns.ac.id \\ DOI: https://dx.doi.org/10.20961/equilibrium.v5i2.54249
}

Article History

Received: 08-08-2021, Accepted: 08-11-2021, Published: 13-12-2021

Kata kunci:

adsorpsi, degumming, kesambi, minyak biji, minyak goreng, minyak, netralisasi

Keywords:

adsorption, cooking oil, degumming, kesambi seed oil, neutralization

\begin{abstract}
ABSTRAK. Minyak biji kesambi (Schleichera oleosa) merupakan salah satu sumber daya yang dapat dimanfaatkan sebagai alternatif pengganti minyak sawit dalam produksi minyak goreng karena kadar air dan bilangan peroksidanya yang lebih rendah. Namun, kandungan asam lemak bebas (FFA) dan asam sianida (HCN) yang tinggi dalam minyak biji kesambi memerlukan pemurnian lebih lanjut sebelum komersialisasi. Pada penelitian ini, proses pemurnian minyak biji kesambi dilakukan dengan teknik degumming, adsorpsi, dan netralisasi. Proses degumming dilakukan dengan menggunakan asam fosfat selama 20 menit. Selanjutnya dilakukan proses adsorpsi menggunakan zeolit $25 \%$ (b/b) selama 14 jam. Proses netralisasi selanjutnya dilakukan dengan natrium hidroksida. Hasil penelitian menunjukkan bahwa sebanyak 32,87 g gum dihilangkan selama proses degumming. Uji asam pikrat membuktikan bahwa adsorpsi menggunakan zeolit mengurangi kandungan HCN, yang menunjukkan bahwa minyak yang diolah aman untuk dikonsumsi. Hasil pengujian FFA menunjukkan bahwa kadar FFA akhir untuk setiap proses berturut-turut adalah 7,25, 6,46, 6,21, 0,17\%. Kajian ini mengungkap potensi minyak biji kesambi sebagai minyak goreng masa depan dengan meningkatkan kualitasnya sehingga dapat memenuhi Standar Nasional Indonesia.
\end{abstract}

\begin{abstract}
Kesambi seed oil (Schleichera oleosa) is one of the resources that can be utilized as an alternative to substitute palm oil in cooking oil production due to its lower moisture content and peroxide value. However, the high level of free fatty acid (FFA) and cyanide acid (HCN) contents in kesambi seed oil require further purification prior to commercialization. In this study, the purification process of kesambi seed oil was carried out with degumming, adsorption, and neutralization techniques. The degumming process was conducted using phosphoric acid for 20 minutes. Afterward, the adsorption process was carried out using $25 \%(\mathrm{w} / \mathrm{w})$ zeolite for $14 \mathrm{~h}$. The neutralization process was subsequently performed with sodium hydroxide. The results showed that as much as $32.87 \mathrm{~g}$ of gum was removed during the degumming process. The picric acid tests verified that the adsorption using zeolite reduced the HCN contents, which indicates that the treated oil is safe to consume. The FFA test results showed that the final FFA content for each process was $7.25,6.46,6.21,0.17 \%$, respectively. This study unfolds the potential of kesambi seed oil as future cooking oil by improving its quality that can satisfy the Indonesia National Standard.
\end{abstract}

\section{PENDAHULUAN}

Minyak goreng merupakan salah satu dari sembilan bahan pokok yang dikonsumsi oleh seluruh lapisan masyarakat Indonesia. Sebagai bahan pangan, minyak goreng berfungsi sebagai penghantar panas, pemberi cita rasa, upaya perbaikan tekstur makanan dan penambah nilai gizi [1]. Umumnya, minyak goreng terbuat dari minyak sawit atau minyak pangan lainnya seperti minyak kedelai atau minyak jagung [2]. Sejauh ini crude palm oil (CPO) masih merupakan bahan baku minyak goreng yang utama karena ketersediaannya yang melimpah di Indonesia. Namun, seiring dengan meningkatnya penggunaan minyak goreng, kebutuhan akan minyak sawit juga terus meningkat. Pemanfaatan minyak sawit juga terjadi pada sektor lain sebagai sumber energi (biodiesel) dan oleokimia. Hal ini menyebabkan adanya persaingan sumber daya minyak sawit untuk digunakan sebagai bahan pangan dan sumber energi terbarukan [3]. Oleh karena itu, perlu dilakukan upaya diversifikasi bahan baku minyak goreng sekaligus pemanfaatan bahan berpotensi lainnya.

Salah satu sumber penghasil minyak nabati yang potensinya belum dimanfaatkan secara optimal adalah biji kesambi (Schleichera oleosa) [4]. Selama ini, minyak biji kesambi cenderung dimanfaatkan sebagai bahan baku alternatif biodiesel maupun obat luar. Biji kesambi merupakan sumber minyak yang potensial karena memiliki kandungan minyak hingga 70\%. Kandungan asam lemak omega dalam minyak kesambi sebesar 60\%, yang lebih 
tinggi jika dibandingkan dengan minyak sawit yang hanya sebesar 53\%[5]. Asam lemak omega terbukti mampu mencegah penyakit-penyakit degeneratif dan meningkatkan perkembangan otak bayi.

Minyak kesambi memiliki kadar air dan bilangan peroksida yang lebih rendah dibanding minyak sawit, yaitu berturut-turut sebesar 0,19\% dan 2,5 meq O2/kg [4]. Namun demikian, meski parameter-parameter tersebut menunjukkan hasil yang baik, kadar asam lemak bebas dalam minyak kesambi masih jauh di atas standar yang ditetapkan oleh SNI. Semakin tinggi kadar asam lemak bebas, minyak cenderung lebih mudah mengalami kerusakan karena pengaruh lingkungan. Mengkonsumsi minyak yang rusak dapat menyebabkan gangguan kesehatan seperti obesitas, peningkatan resiko kanker, resiko penyakit degeneratif, keracunan dalam tubuh, serta deposisi sel lemak pada organ tubuh seperti jantung, ginjal, hati dan arteri [6], [7].

Salah satu sisi yang perlu ditinjau dari penggunaan biji kesambi sebagai bahan pangan adalah adanya kandungan asam sianida (HCN). Hal ini menjadikan minyak tersebut cenderung tergolong sebagai bahan non pangan. Minyak biji kesambi mengandung asam sianida sebanyak 200 ppm yang masih jauh di atas batas aman untuk bahan konsumsi [5], di mana kadar maksimal asam sianida yang diijinkan adalah sebesar $<50 \mathrm{ppm}$ [8]. Mengkonsumsi asam sianida yang melebihi kadar tersebut dapat menyebabkan keracunan. Asam sianida sangat berbahaya bagi kesehatan terutama pada sistem pernapasan, dimana oksigen dalam darah akan terikat oleh senyawa HCN dan menyebabkan terganggunya sistem pernapasan. HCN juga dapat menyebabkan kematian jika dikonsumsi pada dosis 0,5-3,5 mg HCN/kg berat badan [9].

Dengan adanya karakteristik positif maupun negatif dari minyak kesambi di atas, maka diperlukan upayaupaya pemurnian agar minyak tersebut dapat digunakan sebagai minyak pangan atau minyak goreng. Proses pemurnian yang perlu dilakukan terhadap minyak kesambi kasar (crude kesambi oil) meliputi penghilangan getah (degumming) yang lazim terdapat pada minyak hasil ekstraksi, penghilangan HCN dan pengurangan kadar asam lemak bebas.

Penelitian ini menerapkan degumming dengan menggunakan asam fosfat, yang lazim digunakan untuk penghilangan getah pada minyak kasar [10]. Untuk menghilangkan HCN pada minyak dapat digunakan beberapa proses seperti perebusan atau perendaman biji [11], maupun dengan metode adsorpsi. Salah satu adsorben yang dinilai dapat digunakan untuk pemurnian minyak adalah zeolit. Zeolit merupakan mineral berpori dengan kandungan kation alkali yang terdiri dari kristal aluminosilikat terhidrasi. Performa zeolit dalam pemurnian minyak telah dibuktikan oleh Setiawan [12], dimana penambahan zeolit terbukti dapat menurunkan kadar HCN dan asam lemak bebas yang terdapat dalam minyak biji karet. Berdasarkan kemampuan adsorpsi pada zeolit, penambahan zeolit juga diharapkan dapat diterapkan dalam penurunan kadar HCN dan asam lemak bebas minyak biji kesambi. Pengurangan kadar asam lemak bebas pada minyak dapat menggunakan proses netralisasi [13] atau adsorpsi [14]. Netralisasi dengan menggunakan $\mathrm{NaOH}$ telah banyak dilakukan pada skala industri karena dinilai lebih efisien dan murah dibandingkan dengan cara netralisasi lainnya. Selain itu, netralisasi dapat membantu dalam penghilangan zat warna dan kotoran yang berupa getah dan lendir dalam minyak dan lemak [13].

Penelitian ini bertujuan untuk mempelajari proses pemurnian yang meliputi degumming, penghilangan HCN dengan metode adsorpsi dan pengurangan asam lemak bebas (netralisasi) sebagai bahan baku pembuatan minyak goreng.

\section{METODOLOGI}

\subsection{Bahan Penelitian}

Pada penelitian ini, bahan utama yang digunakan adalah minyak biji kesambi yang berasal dari Probolinggo Jawa Timur. Bahan pendukung yang digunakan antara lain: zeolit, akuades, asam fosfat (H3PO4) 85\% (Merck), $\mathrm{NaOH}$ teknis (Merck), etanol 96\% (Merck), silica gel teknis (Merck), indikator PP (Merck), asam tartrat 5\%, Natrium Bikarbonat (Na2CO3) 8\% (Merck) dan asam pikrat jenuh.

\subsection{Peralatan Penelitian}

Peralatan penelitian untuk proses pemurnian minyak goreng terdiri dari: (1) Pemanas stirrer, (2) Labu leher tiga, (3) Pendingin bola, (4) Termometer dan (5) Statif. Peralatan tersebut dirangkai sebagaimana ditunjukkan pada Gambar 1. 


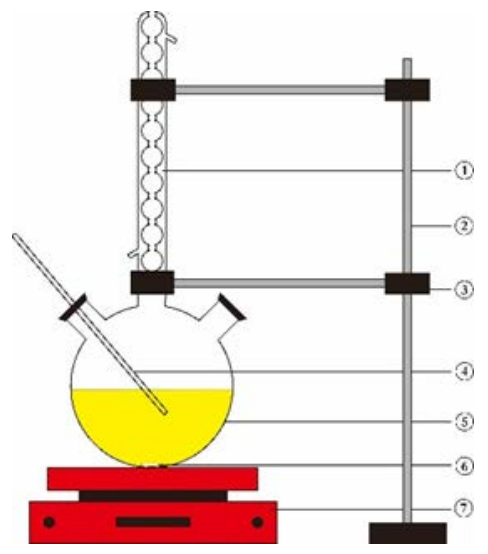

Gambar 1. Rangkaian Alat Proses Pemurnian Minyak Biji Kesambi Sebagai Minyak Goreng

\subsection{Langkah Penelitian}

Proses degumming dilakukan dengan memanaskan minyak biji kesambi, lalu ditambahkan dengan asam fosfat konsentrasi 20\% sebanyak 2,5\% (v/v). Kemudian, minyak disaring menggunakan corong pemisah. Endapan (gum) yang dihasilkan dikeringkan dalam oven suhu $75^{\circ} \mathrm{C}$, sedangkan minyak dicuci menggunakan aquadest sampai $\mathrm{pH}$ buangannya netral (6,5-7). Setelah tidak dihasilkan gum, minyak ditambahkan silica gel, lalu disaring [15].

Penghilangan HCN dilakukan dengan adsorpsi menggunakan zeolit. Minyak hasil degumming ditambahkan dengan zeolit yang telah diaktivasi sebanyak 25\% dari berat minyak. Zeolit ditambahkan untuk menurunkan serta menghilangkan kandungan asam sianida (HCN) dan kadar asam lemak bebas dalam minyak. Kadar HCN dalam minyak diadsorpsi dengan zeolit aktif berukuran 10 mesh selama 14 jam. Minyak yang dihasilan selanjutnya dianalisis HCN-nya secara kualitatif.

Pengujian HCN pada minyak biji kesambi dilakukan dengan maserasi bahan yang telah dioven dalam air dengan perbandingan $1: 1$ dan ditambahkan larutan asam tartrat 5\%. Kertas saring ukuran $1 \times 7 \mathrm{~cm}$ dicelupkan dalam larutan asam pikrat jenuh, kemudian dikeringkan di udara bebas (diangin-anginkan). Setelah kering, kertas saring dibasahi dengan larutan $\mathrm{Na}_{2} \mathrm{CO}_{3} 8 \%$ dan diuapi selama 15 menit pada suhu $50^{\circ} \mathrm{C}$ dengan larutan sampel dan asam tartrat $5 \%$. Apabila warna kuning dari kertas pikrat berubah menjadi warna merah artinya terdapat HCN dalam bahan [16].

Minyak yang bebas HCN kemudian dinetralisasi dengan $\mathrm{NaOH}$ 17\% sesuai dengan kadar asam lemak bebasnya. Minyak yang telah dinetralisasi disaring dengan corong pemisah dan dicuci menggunakan akuades sampai pH buangannya netral (6,5-7). Setelah itu, minyak tersebut ditambahkan dengan silica gel, lalu disaring untuk mengambil filtratnya [13].

Pengujian asam lemak bebas dilakukan dengan metode alkalimetri menggunakan $\mathrm{NaOH}$ 0,1 N. Analisis dilakukan sebanyak 3 kali, yaitu sebelum degumming, setelah degumming, dan setelah adsorpsi dengan zeolit untuk mengetahui seberapa besar penurunan kadar asam lemak pada masing-masing proses.

\section{HASIL DAN PEMBAHASAN}

\subsection{Hasil Degumming}

Penelitian ini diawali dengan degumming minyak biji kesambi mentah untuk memisahkan lendir atau getah (gum) dalam minyak. Degumming perlu disertai dengan pencucian minyak untuk mengantisipasi apabila masih ada gum yang tersisa. Dari hasil degumming awal dihasilkan gum sebesar 14,535 gram. Setelah pencucian, minyak masih menghasilkan gum yang harus dipisahkan. Data perolehan gum pada pencucian minyak tersaji pada Tabel 1. Total jumlah gum yang dihasilkan dari proses degumming dan pencucian sebesar 32,87 gram. Pencucian minyak biji kesambi dilakukan sebanyak 9 kali dengan waktu 30 menit setiap kali pencuciannya. Perhitungan jumlah gum dilakukan setiap 3 kali pencucian. Untuk itu, dibutuhkan waktu selama 270 menit hingga hasil aquadest buangan bersifat netral dengan rentan $\mathrm{pH}$ 6,5-7. 
Tabel 1. Total Jumlah Gum yang Dihasilkan pada Proses Pencucian Minyak Biji Kesambi

\begin{tabular}{cc}
\hline Waktu (menit) & Total Jumlah Gum (gram) \\
\hline 0 & 14,535 \\
90 & 25,647 \\
180 & 30,503 \\
270 & 32,87 \\
\hline
\end{tabular}

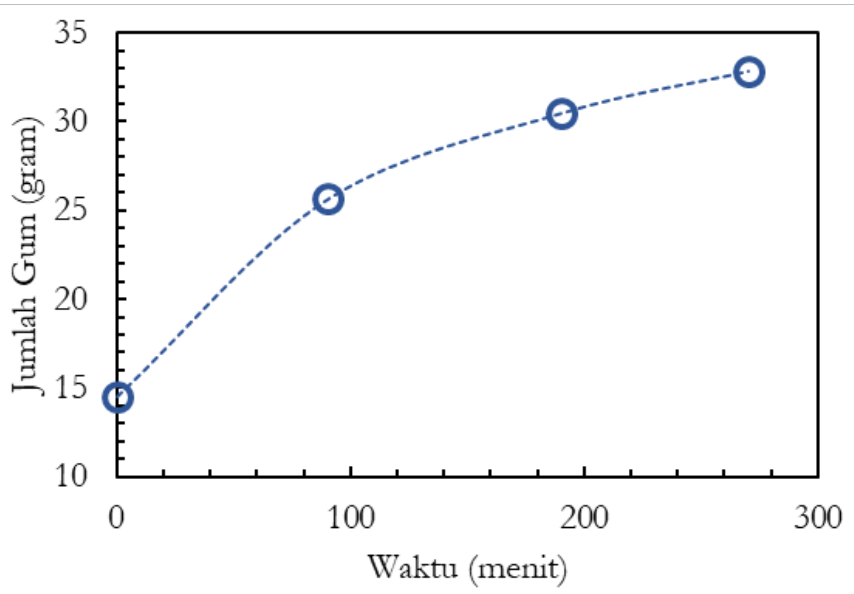

Gambar 2. Grafik Total Jumlah Gum Minyak Biji Kesambi yang Dihasilkan Sebagai Fungsi Waktu Pencucian

Berdasarkan Gambar 2, tampak hasil perolehan gum meningkat seiring dengan lamanya waktu pencucian. Pencucian dilakukan pada variasi waktu 90, 180, dan 270 menit. Dengan penambahan waktu pencucian, maka gum yang terambil semakin meningkat. Waktu pencucian maksimum didapatkan pada 270 menit, seiring dengan hasil buangan aquadest yang bersifat netral

\subsection{Hasil Pengujian Asam Sianida (HCN)}

Minyak yang telah melalui proses degumming selanjutnya diadsorpsi menggunakan zeolit aktif 25\% berat minyak. Minyak hasil adsorpsi dianalisis untuk menunjukkan masih ada atau tidaknya asam sianida di dalamnya. Minyak biji kesambi yang masih berupa crude oil (sebelum mengalami degumming dan adsorpsi) menunjukkan perubahan warna kertas pikrat dari kuning menjadi bercak merah. Perubahan warna kertas pikrat ini merupakan hasil reaksi antara ion pikrat ( $\mathrm{PO}^{-}$) dengan ion $\mathrm{H}^{+}$dari sianida. Reaksi ini terjadi jika asam pikrat dan $\mathrm{HCN}$ mengion [16]. Oleh karena itu, dengan terdapatnya bercak warna merah pada kertas pikrat, maka minyak kesambi terbukti mengandung asam sianida.

Kurnia dan Marwatoen (2013) melakukan pengujian HCN pada singkong dengan menggunakan kertas pikrat. Hasil yang diperoleh menunjukkan bahwa perubahan warna kertas pikrat dari semula kuning menjadi merah bata seluruhnya. Hal ini sedikit berbeda bila dibandingkan dengan hasil uji pada penelitian ini, di mana minyak mentah biji kesambi hanya terdapat sedikit bercak merah. Dengan demikian diyakini bahwa kadar HCN yang terdapat dalam minyak biji kesambi lebih rendah dibandingkan dengan singkong. Oleh karena itu, diharapkan bahwa penghilangan HCN pada minyak biji kesambi akan lebih mudah dilakukan.

Pada pengujian terhadap minyak biji kesambi yang telah diadsorpsi tidak terdapat perubahan warna kertas pikrat. Dengan demikian terbukti bahwa setelah dilakukan proses adsorpsi, asam sianida yang terkandung dalam minyak biji kesambi telah hilang. Hal ini menunjukkan bahwa minyak biji kesambi aman untuk dikonsumsi dan dapat diproses untuk menjadi minyak goreng. Data hasil pengujian dengan asam pikrat disajikan pada Tabel 2.

Tabel 2. Uji Kualitatif Asam Sianida (HCN)

\begin{tabular}{cccc}
\hline Kondisi minyak biji kesambi & Awal & Akhir & Terbaca \\
\hline Crude oil & Kuning & Terdapat bercak merah & Ada \\
Setelah adsorpsi & Kuning & Kuning & Tidak ada \\
\hline
\end{tabular}

Menurut penelitian Munawar (2020), metode kertas pikrat hanya mampu mendeteksi sianida pada konsentrasi sianida terendah sebesar 1 ppm, sehingga penggunaan metode kertas pikrat kurang sensitif karena tidak mampu 
mendeteksi sianida pada konsentrasi lebih rendah dari 1 ppm [17]. Namun pada pengujian minyak biji kesambi yang telah melalui proses adsorpsi, tidak terindikasi adanya perubahan warna kertas pikrat menjadi merah. Dengan demikian dapat diasumsikan bahwa kadar sianida dalam minyak hasil adsorpsi kurang dari 1 ppm sehingga tidak terdeteksi lagi. Menurut Food and Agriculture Organization (FAO), batas maksimum asam sianida yang diijinkan adalah sebesar $<50 \mathrm{ppm}$. Hal ini menunjukkan bahwa batasan kadar sianida dalam minyak yang telah mengalami adsorpsi telah memenuhi standar untuk digunakan sebagai minyak pangan.

\subsection{Hasil Pengujian Kadar Asam Lemak Bebas}

Pengujian kadar asam lemak bebas (Free Fatty Acid-FFA) perlu dilakukan untuk mengetahui apakah minyak kesambi hasil pemurnian telah memenuhi kriteria SNI untuk minyak goreng. Analisis dilakukan pada 3 kondisi, yaitu: sebelum degumming, setelah degumming, dan setelah adsorpsi. Data analisis kadar FFA tersaji pada Tabel 3 dan Gambar 3. Pengujian dilakukan secara triplo agar didapatkan data yang lebih akurat.

Tabel 3. Kadar Asam Lemak Bebas Minyak Biji Kesambi pada Setiap Kondisi

\begin{tabular}{cccc}
\hline Kondisi & Volume NaOH $(\mathrm{mL})$ & Rerata Volume NaOH $(\mathrm{mL})$ & Kadar FFA (\%) \\
\hline Sebelum Degumming & 13,0 & & \\
& 12,8 & 12,80 & 7,25 \\
& 12,7 & & \\
\hline Setelah Degumming & 11,5 & 11,43 & 6,46 \\
& 11,3 & & \\
& 11,5 & \multirow{2}{*}{6,21} \\
\hline Setelah Adsorpsi & 10,8 & & \\
& 11,2 & & 0,17 \\
\hline \multirow{2}{*}{ Setelah Netralisasi } & 11,0 & 0,29 & \\
& 0,28 & & \\
\hline
\end{tabular}

Berdasarkan Gambar 3, terlihat bahwa pada tiap proses yang dilakukan terdapat penurunan kadar FFA dalam minyak biji kesambi. Hal ini membuktikan, bahwa prosedur yang dilakukan telah sesuai dengan tujuan yaitu menurunkan kadar FFA. Kadar FFA minyak biji kesambi yang dihasilkan setelah proses adsorpsi menggunakan zeolit 25\% (b/b) selama 14 jam mengalami penurunan yang semula 6,46\% menjadi 6,21\%. Pada penelitian Setiawan [12] dengan menggunakan berat zeolit dan waktu adsorpsi yang sama memberikan hasil kadar FFA minyak biji karet yang semula 3,14\% menjadi 1,32\%. Pada penelitian ini, terlihat bahwa penurunan kadar FFA minyak biji kesambi tidak lebih baik jika dibandingkan dengan minyak biji karet. Perbedaan signifikansi hasil tersebut dapat terjadi karena perbedaan ukuran zeolit, serta temperatur dan waktu pengovenan proses aktivasi zeolit. Perbedaan hasil adsorpsi menggunakan zeolit ditunjukkan pada Tabel 4.

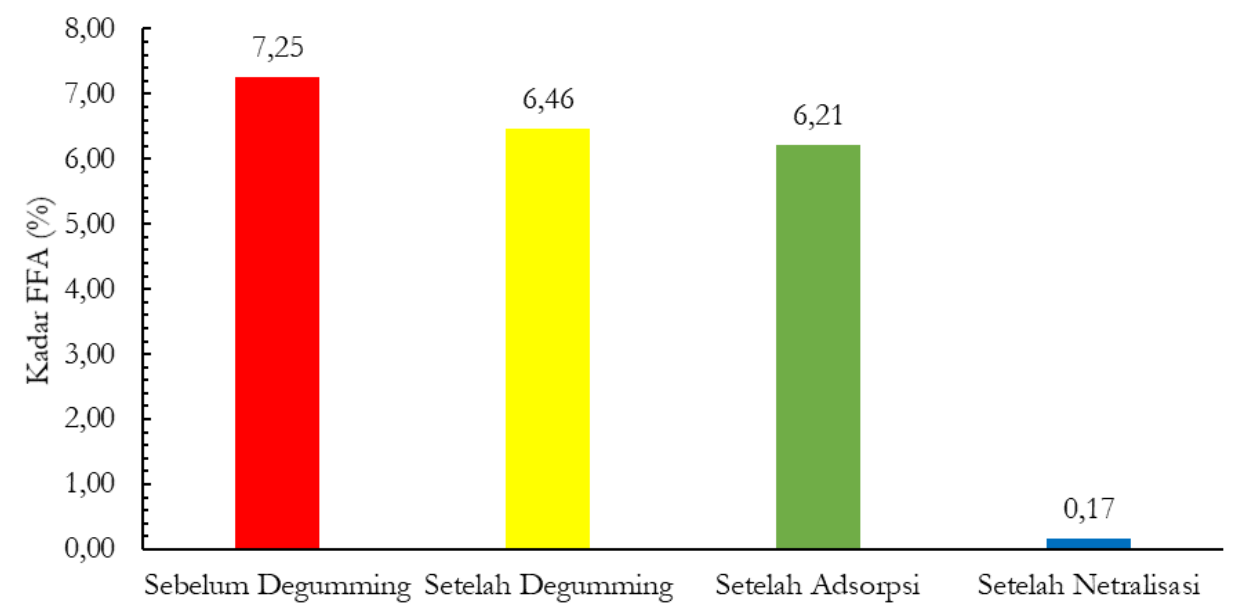

Gambar 3. Grafik Pengujian Kadar FFA dalam Minyak Biji Kesambi pada Berbagai Kondisi 
Tabel 4. Perbandingan kondisi zeolit sebagai adsorben FFA

\begin{tabular}{lcccc}
\hline \multicolumn{1}{c}{ Minyak } & $\begin{array}{c}\text { Ukuran zeolit } \\
\text { (mesh) }\end{array}$ & $\begin{array}{c}\text { Waktu pengeringan } \\
\text { zeolit (menit) }\end{array}$ & $\begin{array}{c}\text { Suhu pengeringan } \\
\text { (menit) }\end{array}$ & $\begin{array}{c}\text { Penurunan } \\
\text { kadar FFA (\%) }\end{array}$ \\
\hline Biji karet [12] & 80 & 15 & 200 & 58 \\
$\begin{array}{l}\text { Biji kesambi } \\
\text { (penelitian ini) }\end{array}$ & 10 & 60 & 50 & 4 \\
\hline
\end{tabular}

Kadar FFA minyak kesambi setelah adsorpsi masih relatif tinggi dan belum memenuhi SNI, sehingga masih diperlukan proses netralisasi dengan $\mathrm{NaOH}$ untuk menurunkannya. Kebutuhan larutan $\mathrm{NaOH}$ untuk menetralkan FFA dapat dihitung dengan persamaan (1) untuk setiap gram minyak :

$$
\% \mathrm{NaOH}\left(\frac{\mathrm{b}}{\mathrm{b}}\right)=\frac{(0,142 \times \% \text { FFA })+\text { excess } \mathrm{NaOH}}{\text { konsentrasi } \mathrm{NaOH}} \times 100
$$

Pada persamaan (1) ini, konsentrasi $\mathrm{NaOH}$ yang digunakan adalah 17\% dan \% FFA dihitung sesuai kadar FFA setelah adsorpsi (6,21\%). Minyak yang dihasilkan setelah netralisasi telah menunjukkan $\mathrm{pH}$ netral.

Secara keseluruhan, proses pemurnian ini mengurangi jumlah minyak yang dihasilkan (rendemen) pada tiap tahapannya. Tabel 5 menunjukkan rendemen minyak yang diperoleh sebelum degumming, setelah degumming dan setelah adsorpsi. Proses degumming menurunkan berat minyak dari semula 446,12 gram menjadi 371,775 gram sehingga terjadi kehilangan massa sebesar 74,345 gram. Menilik dari berat gum yang berhasil dipisahkan, yaitu hanya sebanyak 32,87 gram, maka terdapat 41,475 gram massa hilang yang terjadi akibat proses pencucian dan penyaringan. Untuk ini perlu diteliti lebih lanjut proses yang lebih efektif dan efisien untuk mengurangi kehilangan massa yang terlalu besar dan cenderung merugikan ini.

Pada proses adsorpsi dengan zeolit, massa minyak yang hilang sebesar 147,475 gram, yang secara nyata lebih besar dibandingkan kehilangan akibat proses degumming. Hal ini juga menunjukkan bahwa proses adsorpsi dengan zeolit memiliki sisi kelemahan yang mengakibatkan kehilangan massa secara signifikan. Massa yang hilang ini kemungkinan disebabkan oleh tertinggalnya sisa minyak di dalam pori-pori adsorben.

Sebagai gambaran untuk penelitian selanjutnya, maka rendemen minyak setelah 2 tahap pemurnian ini sekitar $50 \%$. Dengan demikian, untuk menghasilkan minyak kesambi kualitas refined (minyak murni), diperlukan minyak kesambi kasar sejumlah 2 kalinya.

Tabel 5. Rendemen minyak biji kesambi setelah pemurnian

\begin{tabular}{lccc}
\hline \multicolumn{1}{c}{ Kondisi } & Berat minyak, gr & Pengurangan berat minyak, gr & Rendemen, \% \\
\hline Sebelum Degumming & 446,12 & & \\
Setelah Degumming & 371,775 & 74,345 & 83,34 \\
Setelah Adsorpsi & 224,3 & 147,475 & 50,28 \\
\hline
\end{tabular}

\section{KESIMPULAN}

1. Minyak goreng kesambi dapat dihasilkan dari pemurnian minyak kasar biji kesambi yang meliputi degumming, adsorpsi dengan zeolit dan netralisasi.

2. Semakin lama waktu pencucian, gum yang terambil semakin banyak.

3. Penghilangan HCN berhasil dilakukan dengan proses adsorpsi menggunakan zeolit 25\%. Hasil pengujian kandungan HCN dalam minyak biji kesambi setelah diadsorpsi menunjukkan bahwa tidak ditemukan HCN pada minyak tersebut, sehingga minyak goreng kesambi yang telah dimurnikan relatif aman untuk dikonsumsi.

4. Kadar asam lemak bebas dapat diturunkan dengan degumming, adsorpsi dan netralisasi.

\section{UCAPAN TERIMA KASIH}

Penulis mengucapkan terima kasih kepada Belmawa Dikti dan Biro Kemahasiswaan UNS yang telah membantu dalam pendanaan dan memfasilitasi pelaksanaan Program Kreativitas Mahasiswa tahun 2021

\section{DAFTAR PUSTAKA}

[1] Mardiah, S. R. R. Pertiwi, dan D. Marwana, "Analisis Mutu Minyak Goreng Dengan Pengulangan Penggorengan,” Pangan Halal, vol. 1, no. 1, hal. 1-8, 2019. 
[2] B. Yasri, K. N. Hikmah, dan O. M. Rosandhi, "Perancangan Alat Uji Kandungan Peroksida (H2O2) Pada Minyak Goreng Menggunakan Light Dependent Resistor,” AGRITEPA J. Ilmu dan Teknol. Pertan., vol. 6, no. 2, hal. 1-12, 2019, doi: 10.37676/agritepa.v6i2.877.

[3] Z. Amrullah, M. F., Saputra E., Helwani, "Pembuatan Biodiesel dari Miyak Nyamplung (Calophyllum Inophyllum) Menggunakan Katalis Geopolimer: Pengaruh Temperatur dan Rasio Mol Minyak: Metanol,” JOM FTEKNIK, vol. 4(2), 2017.

[4] Y. M. Tamara, W. N. Hidayat, N. A. Azizah, dan D. A. Setyawardhani, "Pemanfaatan Minyak Biji Kesambi ( Schleichera Oleosa ) Sebagai Alternatif Pengganti Minyak Goreng Sawit,” J. Chem. Process Eng., vol. 5, no. 2, hal. 1-7, 2020.

[5] K. Heyne, Tumbuhan Berguna Indonesia Badan Penelitian dan Pengembangan Kehutanan. Departemen Kehutanan, 1987.

[6] M. Megawati dan Muhartono, "Konsumsi Minyak Jelantah dan Pengaruhnya terhadap Kesehatan,” Majority, vol. 8, no. 2, hal. 259-264, 2019.

[7] H. N. Muhammad, F. Nikmah, N. U. Hidayah, dan A. K. Haqiqi, “Arang Aktif Kayu Leucaena Leucocephala sebagai Adsorben Minyak Goreng Bekas Pakai (Minyak Jelantah),” Phys. Educ. Res. J., vol. 2, no. 2, hal. 123, 2020.

[8] F. G. Winarno, Kimia Pangan dan Gizi. Jakarta: PT. Gramedia Pustaka Utama, 2002.

[9] Siboro R, "Reduksi Kadar Sianida Tepung Ubi Kayu (Manihot esculenta crantz ) Melalui Perendaman Ubi Kayu dengan NaHCO3,” Repository.Unib.Ac.Id, hal. 1-37, 2016.

[10] D. A. Setyawardhani, N. I. Nurbaiti, dan N. R. Prambasati, "Degumming pada Minyak Kasar Kacang Tanah,” 2008.

[11] D. A. Setyawardhani, H. S. Alkautsar, dan U. R. Fadhilah, "Pengolahan Biji Karet sebagai Bahan Baku Pembuatan Minyak Pangan (Edible Oil),” Ekuilibrium, vol. 12, no. 1, hal. 23-26, 2013.

[12] F. Setiawan, A., Pato, U., Hamzah, "Pemurnian Minyak Goreng dari Biji Karet (Havea Brasiliensisroxb.,) Menggunakan Zeolit,” JOM FAPERTA, vol. 3(1), 2016.

[13] Y. Kurniati dan W. H. Susanto, "Pengaruh Basa NaOH dan Kandungan ALB CPO terhadap Kualitas Minyak Kelapa Sawit Pasca Netralisasi,” J. Pangan dan Agroindustri, vol. 3, no. 1, hal. 193-202, 2015.

[14] D. W. Aji dan M. N. Hidayat, "Optimasi Pencampuran Carbon Active dan Bentonit sebagai Adsorben dalam Penurunan Kadar FFA (Free Fatty Acid) Minyak Goreng Bekas melalui Proses Adsorpsi," eprints.undip.ac.id, hal. 1-5, 2011.

[15] M. M. K. Madya, M. N. A., Aziz, Process Design in Degumming and Bleaching of Palm Oil, Vote No. 7. Malaysia: Centre of Lipids Engineering and Applied Research (CLEAR), 2006.

[16] N. Kurnia dan F. Marwatoen, "Penentuan Kadar Sianida Daun Singkong Dengan Variasi Umur Daun Dan Waktu Pemetikan,” Hydrog. J. Kependidikan Kim., vol. 1, no. 2, hal. 117, 2013.

[17] H. Munawar dan F. Ramadhani, "Studi Pendahuluan Pembuatan Prototipe Sensor untuk Deteksi Keracunan Sianida Pakan Hijauan Ruminansia dengan Metode Cyclic Voltammetry ( A Preliminary Study of Sensor Prototype for Measurement of Cyanide Toxicity in Forage Ruminant by Cyclic Voltammetry M," Pros.Semnas.TPV-2020, hal. 858-871, 2020. 